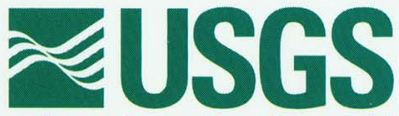

science for a changing world

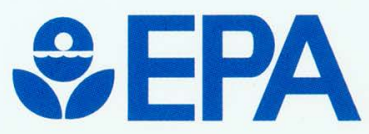

\title{
Digital Geologic Map of Sherman Quadrangle, North Central Texas
}

By Jason R. Masoner, David S Burden,

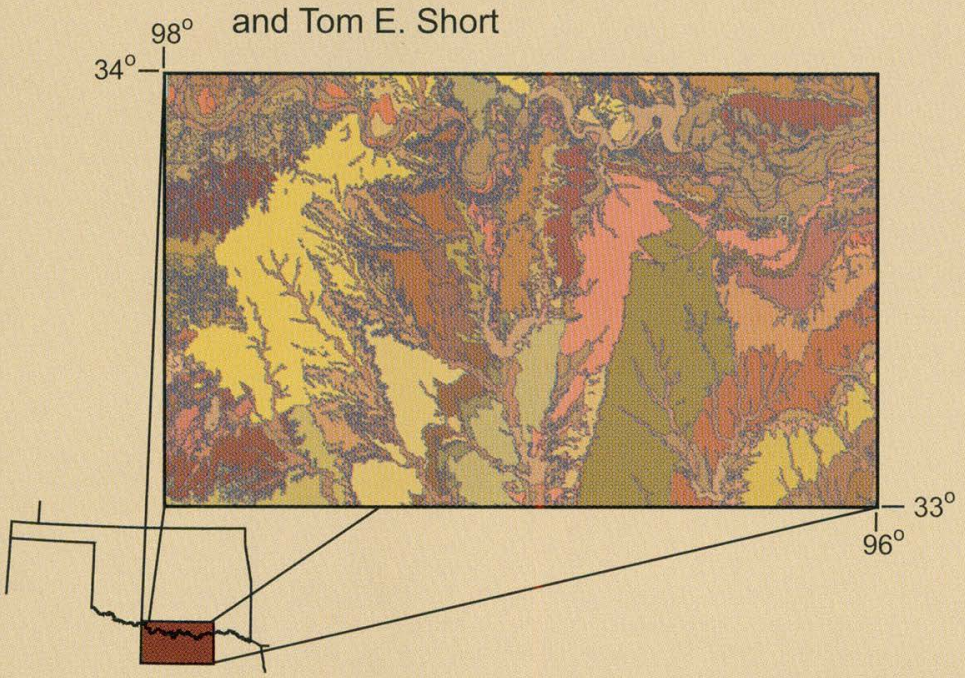

U.S. Department of the Interior

Open File Report 02-264 U.S. Geological Survey 


\section{Digital Geologic Map of Sherman Quandrangle, North Central Texas}

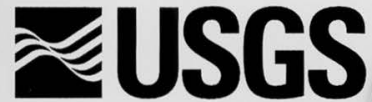

science for a changing world
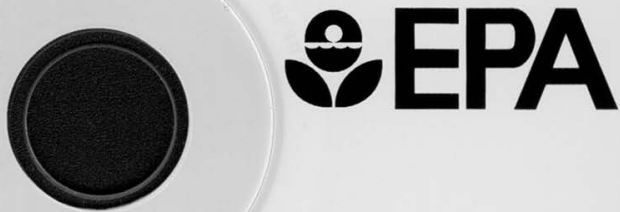

by Jason R. Masoner, David S. Burden, and Tom E. Short

Open File Report 02-264 U.S. Department of the Interior U.S. Geological Survey 


\section{Digital Geologic Map of Sherman Quandrangle, North Central Texas}

This compact disc contains digital data sets of the surficial geology and geologic faults for the 1:250,000 - scale Sherman quadrangle, North Central Texas, and can be used to make geologic maps, and determine approximate areas and locations of various geologic units. The source data are from the Bureau of Economic Geology publication, Geologic Atlas of Texas, Sherman Sheet.

Data sets are provided in an ARC/INFO coverage and interchange file formats. The coverage format can be used from this compact disc. The interchange files have been compressed and have an ".exe" extension and can be uncompressed by double clicking on the ".exe" files.

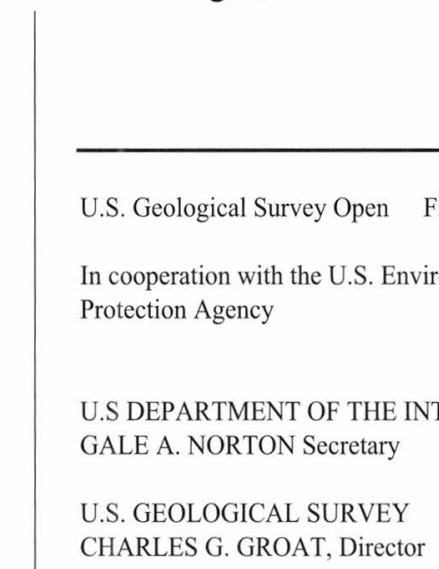

